\section{Administrative Measures in Puerperal Fever}

Investigations carried out for the Departmental Committee on Maternal Mortality have shown the importance of strains of the micro-organism known as the hæmolytic streptococcus, and of carriers of this organism, in the causation of puerperal fever. The Ministry of Health, in a circular recently issued to Medical Officers of Health, therefore recommends on the occurrence of fever in a lying-in woman the isolation and separate nursing of the patient, and investigations to determine the nature of the infecting organism and possible sources of infection. The lastnamed include bacteriological investigation of the patient and of those who may have been in contact with her during labour and for 48 hours afterwards. As contact with hands and instruments is the most likely mode of infection of the genital tract, attention should be directed to infections or abrasions of the skin of anyone who has had contact with the patient.

\section{Swedish Meteorology}

Among recent publications of the Swedish Meteorological and Hydrographical Office are the detailed observations from the observatory at Riksgransen on Vassijaure in Swedish Lapland for the year 1931 (Arsbok, 13, 1931). Full records are given for every hour on each day of the year, with additional notes on the freezing of the lake, aurora borealis and other matters. Another publication (Årsbok, 15, 1933) records the rainfall of Sweden. Monthly figures are given for each station with summaries for various districts and comparisons with the mean average figures. There are also rainfall maps for each month and for the year. It is noticeable that the year under review showed nearly everywhere in Sweden a considerable deficiency compared with the normal rainfall. A third publication treats of the weather of 1933 (Arsbok, 15, 1933) in a series of monthly surveys with comparisons with the means.

\section{Plant Pathology at the Seale-Hayne Agricultural College}

THE tenth annual report of the Department of Plant Pathology of the Seale-Hayne Agricultural College, Newton Abbot, Devon, contains several interesting articles by the entomologist (Mr. L. N. Staniland) and the mycologist (Mr. A. Beaumont). The general activities of the Department are reviewed, and reveal a very efficient and progressive organisation. Short articles appear on "The Spread of Potato Eelworm in Consignments of Seed Potatoes", "The Alternative Host Plants of the Violet Aphis", "Violet Eelworm" and "Notes on Hot Water Treatment of Strawberry Runners" together with several paragraphs describing its effects on various pests. A useful article on "Narcissus Disease and Pest Control Calendar" guides the grower in the general treatment of his bulbs (a study which is somewhat neglected by many home gardeners) in addition to discussing the control of pests and diseases. More general notes on insect and fungus maladies which have oceurred during the year, and lists of those found in Devon and Cornwall, are also given.

\section{'Insulin-Boots'}

WE have received from Messrs. Boots Pure Drug Co., Ltd., Nottingham, an illustrated booklet describing the preparation and uses of InsulinBoots. The insulin is extracted from frozen pancreas glands by mincing into an alcoholic solvent; further treatment of the solution is necessary to remove the bulk of the inactive protein. The resulting clear solution is concentrated at low temperature by vacuum distillation. After removal of fat the insulin is precipitated by addition of salt and further purified by fractional precipitation in the iso-electric range and from various solvents. The booklet describes the tests to which each batch is submitted, the properties of insulin and its use in diabetes and in nondiabetic conditions. A useful section is a detailed account of the technique of subcutaneous injection. Insulin-Boots is issued in three strengths, 20,40 and 80 units per c.c.

\section{Announcements}

The Right Hon. The Earl of Malmesbury has consented to become president of the next Health Congress of the Royal Sanitary Institute, which is to be held at Bournemouth on July 15-20, 1935.

The B.B.C. announces that the public experiment with the 24-hour system of timing, which began in April, will end on August 18. It is stated that the system has been effectively introduced to the public, but there has been no evidence of either widespread support or opposition for it.

The Autumn Meeting of the Iron and Steel Institute will be held in Belgium and Luxemburg on September 10-14. The programme includes visits to the principal iron and steel manufacturing and engineering works of the two countries. Advance copies of papers to be read can be obtained from the secretary of the Institute.

Applications are invited for the following appointments, on or before the dates mentioned:- Junior technical assistants (temporary) under the Director of Ordnance Factories-Under-Secretary of State (C.5), War Office, London, S.W.1 (Aug. 22). A county dairy instructor (male) to the Wilts County Council-Clerk of the Council, County Offices, Trowbridge, marked "County Dairy Instructor" (Aug. 27). An engineer sub-lieutenant in the Royal Indian Marine-Secretary, Military Department, India Office, Whitehall, S.W.1, marked "Royal Indian Marine Recruitment" (Aug. 31). An adviser in agricultural zoology at University College, Cardiff-The Registrar (Sept. 1). A head of the Engineering Department, St. Helens Municipal Technical School-The Secretary for Education, Education Office, St. Helens. A public analyst for the Boroughs of Kensington and Hammersmith-Town Clerk, Kensington, W.8. (Sept. 7). University readerships at the British PostGraduate Medical School in medicine, surgery, obstetrics and gynæcology, pathological chemistry and bacteriology-Academic Registrar, University of London, S.W.7 (Sept. 17). 